\title{
Analisis Sikap Siswa pada Pembelajaran IPA di SDN 124/VIII Sidorejo Kabupaten Tebo
}

\author{
Paino $^{1}$, Wisnu Desmawan ${ }^{2}$ \\ ${ }^{1,2}$ SDN 124/VIII Sidorejo, Jambi, Indonesia
}

\begin{tabular}{l} 
Article Info \\
\hline Article history: \\
Received Mei 12, 2020 \\
Revised Mei 23, 2020 \\
Accepted Mei 26, 2020 \\
\hline
\end{tabular}

\section{Keywords:}

Pembelajaran IPA

Sikap Siswa

Sekolah Dasar

\begin{abstract}
Tujuan penelitian: Sikap merupakan salah satu instrumen penting yang harus dimiliki oleh seorang siswa. Penelitian ini bertujuan untuk mengetahui siskap siswa SDN 124/VIII Sidorejo pada pembelajaran IPA.
\end{abstract}

Metodologi: Penelitian ini mengunakan jenis penelitian kuantitatif jenis survey dengan teknik pengambilan data berupa angket dan wawancara yang diolah menggunakan SPSS 21 dengan teknik statistik deskriptif.

Temuan utama: Hasil temuan penelitian ini yaitu dari 125 siswa yang kemudian hasilnya di olah dan dimasukkan ke dalam 5 kategori, sikap IPA siswa di SDN 124/VIII Sidorejo terdapat kecenderungan atau lebih dominan ke dalam kategori baik dengan persentase sebesar 50\%. Sedangkan pada kategori sangat baik sebesar $10 \%$, pada kategori cukup baik sebesar $25 \%$, kategori tidak baik sebesar $10 \%$ dan kategori sangat tidak baik sebesar 5\%.

Keterbaruan penelitian: Keterbaruan dalam penelitian ini yaitu untuk menganaslisi sikap IPA siswa dengan indikator implikasi sosial IPA di SDN 124/VIII Sidorejo.

This is an open access article under the CC BY-NC license

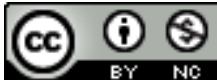

\section{Corresponding Author:}

Paino,

SDN 124/VIII Sidorejo, Kecamatan Rimbo Ilir

Email: paino@gmail.com

\section{INTRODUCTION}

Pendidikan dewasa ini sudah masuk sebagai kebutuhan dasar yang diperlukan sebagai kebutuhan dasar manusia. Pendidikan dipandang sebagai usaha yang dilakukan untuk secara aktif mengembangkan potensi diri melalui jalan proses pembelajaran. Pendidikan adalah sebuah usaha yang dilakukan secara sadar dan terencana untuk mewujudkan suasana belajar dan proses pembelajaran agar peserta didik secara aktif mengembangkan potensi dirinya untuk memiliki kekuatan spiritual keagamaaan, membangun kepribadian, pengendalian diri, kecerdasan, akhlak mulia, serta keterampilan diperlukan dirinya, masyarakat, bangsa, dan negara [1]. Proses pendidikan yang dilaksanakan sejak dini bertujuan untuk menggali dan meningkatakan kemampuan diri, penguatan karakter diri, dan pengetahuan. Syahrial [2] Education is a very important activity, with the education of humans can change behavior and knowledge for the better. Nilai-nilai dalam proses pembelajaran menjadi penting bukan hanya sebagai usaha untuk meningkatkan potensi, karakter dan pengetahuan tapi pembelajaran juga berperan penting dalam menjadikan manusia sebagai manusia seperti fitrahnya. Education is a processor effort carried out by someone to gain knowledge, skills, and habits in life [3].

Pembelajaran yang dilakukan disekolah sangat erat hubungannya dengan pelaksanaan kurikulum. [4] Kurikulum 2013 di sekolah mengantikan kurikulum tingkat satuan pendidikan. Secara konseptual, kurikulum adalah suatu respon pendidikan terhadap kebutuhan masyarakat dan bangsa dalam membangun 
generasi muda bangsa. Kurikulum yang berlaku saat ini di Indonesia adalah Kurikulum 2013 revisi (K13 revisi). Kurikulum 2013 lebih ditekankan pada pendidikan karakter, terutama pada tingkat dasar, yang akan menjadi fondasi bagi tingkat berikutnya [5]. Pengembangan kurikulum dilaksanakan sebagai langkah untuk peningkatan mutu pendidikan. Disamping itu, inovasi-inovasi dalam dunia pendidikan harus disesuaikan dengan pengembangan kurikulum. This is then a curriculum should be developed by the right team with reference to local knowledge, but still considers the strengt and weaknesses of the previous curriculum [6]. Salah satu unsur inovasi yang perlu menjadi perhatian mendasar yaitu siswa diharapkan memiliki sikap yang ilmiah dalam proses pembelajaran.

Salah satu sikap ilmiah yang dapat mendukung kurikulum 2013 revisi yaitu pada konsep pembelajaran IPA dalam pembelajaran tematik. Sikap ilmiah yang dapat mendukung kurikulum 2013 revisi adalah mata pelajaran IPA yang secara keseluruhan menjadi patokan apakah peserta didik mampu mengikuti pembelajaran sesuai kurikulum yang diterapkan di sekolah [7]. Pembelajaran IPA di sekolah dasar dilaksanakan secara tematik atau terintegrasi yang dipadukan dengan pembelajaran lainnya. Sikap ilmiah pada pembelajaran IPA pada tingkat sekolah dasar, siswa diajak untuk memahami dan menemukan konsepkonsep ilmiah IPA serta kemampuan malakukan percobaan ilmiah sederhana. Knowledge of the subject matter includes familiarity with the concepts and their relationships, rules, problem solving skills, connections within and between topics, various forms of accurate information representation, and methods of acquiring and applying knowledge just to mention a few [8]. Salah satu aspek keberhasilan siwa dalam proses mamahami proses pembelajaran yang disampaikan guru menunjukan sikap positif siswa. Salah satu indikator yang dapat digunakan untuk mengukur sikap ilmiah IPA siswa yaitu aspek implikasi sosial IPA siswa.

Implikasi sosial yang dimiliki oleh seorang siswa pada konsep pembelajaran IPA menjadi sangatlah penting. Dimensi implikasi sosial dari IPA akan lebih bermakna jika peserta didik dapat mengendalikan dirinya dalam pencapaian tujuan dari pendidikan. sebab, implikasi sosial siswa dapat membentuk berbagai sikap yaitu kemandirian siswa dan kemampuan siswa dalam menjalin kegatan kerja sama dengan rekan sejawan saat pembelajaran IPA [9]. Implikasi sosial dapat membentuk sikap kemandirian, kerjasama siswa dalam proses pembelajaran [10]. Kemandirian siswa dapat dilihat bagaimana siswa dapat secara penuh tanggung jawab dalam melaksanakan tanggung jawabnya yang telah diberikan padanya. Sedangkan sikap kerjasama siswa dapat dilihat bagaimana siswa dapat menjalakan sebuah kegiatan secara bersama-sama dengan teman sejawatnya misalnya saat guru membentuk siswa dalam sebuah kelompok atau saat guru memberikan sebuah masalah yang harus dipecahkan secara bersama-sama.

Tujuan penelitian ini yaitu ingin menjabarkan sikap siswa pada konsep pembelajaran IPA yaitu bagaimana sikap implikasi sosial siswa terhadap Mata Pelajaran IPA di SDN 124/VIII Sidorejo Kabupaten Tebo?.

\section{METODE PENELITIAN}

Metode penelitian yang digunakan oleh peneliti adalah penelitian kuantitatif yang menggunakan desain penelitian adalah penelitian survei. Survey research is a procedure in quantitative research where researchers administer surveys to a sample or to the entire population used to describe population attitudes, opinions, behaviors, or special characteristics [11]. [12] Arah penelitian survei adalah untuk menganalisis karakteristik-karakteristik dari populasi dengan jumlah besarPopulasi pada penelitian ini berjulah 125 siswa SDN 124/VIII Sidorejo. Teknik pengumpulan data yang digunakan yaitu angket dan wawancara. Data yang didapatkan akan diolah menggunakan SPSS dengan statistik deskriptif.

\section{HASIL DAN PEMBAHASAN}

Indikator yang diteliti pada aspek Implikasi sosial siswa pada sikap siswa dalam pembelajaran IPA disekolah dasar meliputi kegiatan penuh tanggungjawab dan jujur dalam melaksanakan tugas, mengerjakan tugas secara mandiri tanpa meminta batuan dengan orang lain, berkomunikasi dengan rekan sejawat, dan menjalin kerjasama dengan rekan sejawat dalam melaksanakan tugas kelompok yang diberikan guru. Berdasarkan berbagai indikator diatas diperoleh data sebagai berikut : 
Tabel 1. Ststistik Deskriptif Implikasi Sosial pelajaran IPA

\begin{tabular}{lcccccccc}
\hline No & Kategori & frekuensi & $\begin{array}{c}\text { Standar } \\
\text { Deviasi }\end{array}$ & Modus & Mean & Median & Min & max \\
\hline $\mathbf{1}$ & Sangat baik & 13 & & & & & & \\
$\mathbf{2}$ & Baik & 63 & & & & & & \\
$\mathbf{3}$ & Cukup baik & 31 & 2,50 & 25 & 23 & 25 & 15 & 35 \\
$\mathbf{4}$ & Tidak baik & 12 & & & & & & \\
$\mathbf{5}$ & Sangat tidak baik & 6 & & & & & & \\
\hline
\end{tabular}

Berdasarkan tabel 1, diketahui bahwa data yang telah didapatkan menggunakan instrumen angket kemudian diolah menggunakan SPSS 21 dengan hasil yaitu standar deviasi sebesar 2,50, modus sebesar 25, mean sebesar 23, median sebesar 25. Selain itu juga didapat nilai maksimal sebesar 35 dan nilai minimal sebesar 15 .

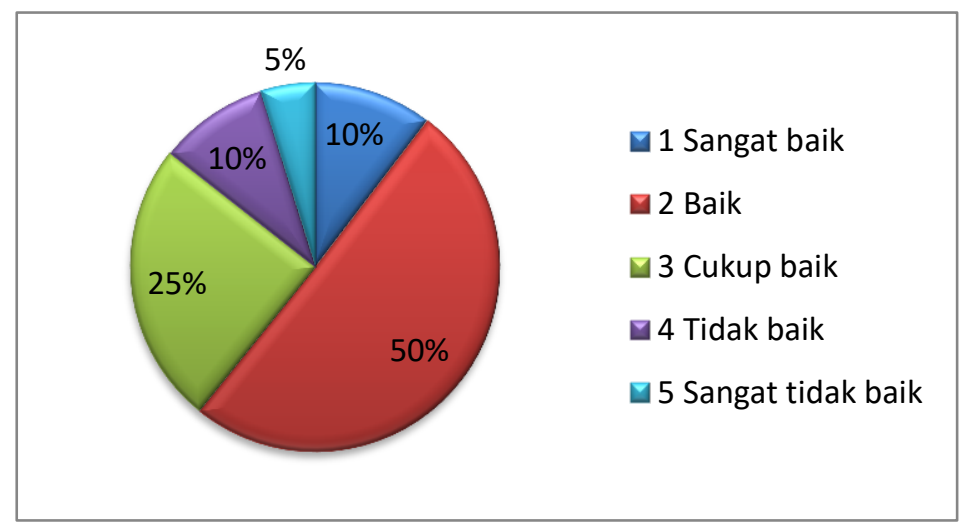

Diagram 1. Persentase Implikasi sosial sikap IPA siswa

Berdasarkan diagram 1 diatas, implikasi sosial sikap IPA siswa di SDN 124/VIII Sidorejo didapatkan data sebagai berikut : dari 125 siswa yang kemudian hasilnya di olah dan dimasukkan ke dalam 5 kategori, sikap IPA siswa di SDN 124/VIII Sidorejo terdapat kecenderungan atau lebih dominan ke dalam kategori baik dengan persentase sebesar 50\%. Sedangkan pada kategori sangat baik sebesar 10\%, pada kategori cukup baik sebesar 25\%, kategori tidak baik sebesar $10 \%$ dan kategori sangat tidak baik sebesar 5\%. Berdasarkan hasil diatas dapat diartikan bahwa siswa di SDN 124/VIII Sidorejo memiliki kecenderungan sikap yang baik pada pembelajaran IPA. Siswa menganggap bahwa pembelajaran IPA sangat menyenangkan, mudah dipahami dan dimengerti. Siswa akan lebih menyenangi pembelajaran IPA dengan pembelajaran yang aktif seperti percobaan, pengamatan langsung atau eksperimen. Pembelajaran yang aktif menjadikan siswa lebih bersemangat dalam melaksanakan proses pembelajaran.

Implikasi sosial sikap IPA siswa adalah salah satu indikator yang sangat penting bagi siswa. [13] Peserta didik yang memiliki sikap ilmiah yang tinggi akan membantu proses pembalajaran sains dan fisika menjadi lebih baik. Hal ini dikarenakan sikap ilmiah dapat membentuk peserta didik berfikir secara kreatif dan kritis.Pembelajaran IPA disekolah dasar mempelajari seputar konsep dasar IPA itu sendiri. [14] IPA merupakan konsep pembelajaran alam dan mempunyai hubungan yang sangat luas terkait dengan kehidupan manusia. Artinya dalam pembelajaran IPA disekolah dasar siswa dikenalkan tentang konsep-konsep IPA kemudian diajak untuk membuktikan tentang konsep tersebut melalui sebuah pengalaman pembelajaran secara langsung misalnya melalui pembelajaran dengan eksperimen, pengamatan langsung dan pembuktian. [15] IPA adalah pengetahuan yang dibentuk melalui proses pengamatan terhadap gejala-gejala alam dan kebendaan secara rasional dan obyektif melalui observasi atau pengamatan, klasifikasi, komunikasi, dan interprestasi data dengan menggunakan metode ilmiah. Melalui implikasi sosial sikap IPA siswa diajak untuk menemukan sisi yang menarik dan menantang pada pembelajaran IPA. Pembelajaran yang menarik diharapkan dapat meningkatkan motivasi siswa dengan sendirinya. [16] Guru harus dapat merancang proses pembelajaran dan menyajikan materi secara kreatif dan inovatif. Ketika siswa telah memiliki ketertarikan pada pembelajaran IPA, siswa dengan sendirinya menganggap bahwa pembelajaran IPA adalah pembelajaran yang mudah dan menyenangkan. Sikap sosial IPA siswa sangat penting bagi siswa karena sangat berdampak positif pada diri siswa dalam memandang dan menghadapi kondisi yang sulit serta dapat merespon lingkungannya secara positif. [17] Sikap siswa merupakan salah satu kunci dalam pembelajaran IPA.

Berdasarkan hasil angket pada tabel 1 dan diagram 1 menunjukan bahwa siswa SDN 124/VIII Sidorejo terdapat kecenderungan atau lebih dominan baik dengan persentase $50 \%$ pada aspek sikap terhadap 
pembelajaran IPA. Siswa menunjukan sikap yang baik saat pembelajaran IPA dilaksanakan, mayoritas siswa merasa bahagia dan aktif saat proses pembelajaran. Siswa mampu bekerja sama dengan teman sejawatnya dalam mengerjakan tugas atau percobaan yang difasilitasi oleh guru kelas. Akan tetapi masih terdapat siswa yang menunjukan sikap cuek dan tidak aktif pada saat pembelajaran dilaksanakan. Terjadinya interaksi dalam pembelajaran antara siswa, guru dan siswa lainnya akan menimbulkan proses sosial yang sehat didalam kelas.

Hasil wawancara diperoleh dari pertanyaan tentang sikap siswa terhadap mata pelajaran IPA pada indikator implikasi sosial IPA adalah sebagai berikut:

Pertanyaan 1 : Apakah Anda merasa suka pada saat belajar IPA ?

Jawab : ya, suka sekali

Pertanyaan 2 : Jelaskan alasan mengapa Anda suka belajar IPA ?

Jawab : saya suka belajar IPA karena pada saat belajar IPA saya merasa dekat dengan lingkungan.

Karenakan belajar IPA itu mempelajari seperti hewan, tumbuhan dan manusia.

Pertanyaan 3 : Apakah belajar IPA bermanfaat menurut Anda ? Jelaskan?

Jawab : sangat bermanfaat sekali, jadi kita belajar tentang apa yang ada di lingkungan kita sendiri.

Sementara berikut jawaban siswa yang memiliki sikap IPA yang kurang baik.

Pertanyaan 1 : Apakah anda merasa suka pada saat belajar IPA ?

Jawab : kadang suka, tapi kadang-kadang tidak suka

Pertanyaan 2 : Jelaskan mengapa anda kadang merasa suka dan terkadang tidak ?

Jawab : menurutku pelajaran IPA agak sulit, tapi aku lebih suka pelajaran Olahraga. Aku suka main bola.

Berdasarkan hasil wawancara yang telah dilakukan dengan narasumber, data tersebut menunjukan bahwa siswa dengan sikap implikasi IPA yang baik memilki ketertarikan dan motivasi yang baik. Siswa mampu memandang bahwa IPA merupakan pembelajaran yang menarik dan menyenangkan. Pembelajaran IPA juga memangdang hal-hal yang dekat dengan kehidupan siswa. Dengan demikian siswa memandang bahwa pembelajaran IPA memiliki manfaat yang dapat digunakan dalam kehidupan sehari-hari. Sementara siswa dengan sikap implikasi IPA yang kurang baik masih memandang bahwa pembelajaran IPA adalah pembelajaran yang sulit. Dengan pandangan seperti demikian siswa memiliki ketertarikan pada pembelajaran IPA yang cenderung rendah. [18] Sikap siswa merupakan salah satu kunci dalam pembelajaran IPA. [19] That attitude comes from within the learner himself, namely the feeling of an object that is shown in feelings of like or dislike.

\section{KESIMPULAN}

Berdasasarkan hasil penelitian mengenai sikap sosial siswa dengan indikator implikasi sosial siswa menunjukkan bahwa siswa memiliki kecenderungan atau dominan ke dalam kategori baik. Pada saat pembelajaran siswa telah menunjukan interaksi sosial yang baik, saling bekerja sama dan memiliki kemandirian dalam belajar. Akan tetapi masih terdapat siswa yang masih belum memiliki sikap sosial yang kurang baik. Siswa masih belum memiliki ketertarikan dan motivasi terhadap pembelajaran IPA. Oleh karena itu guru sebagai fasilitator didalam kelas harus senantiasa merancang pembelajaran yang baik dan menarik. Sehingga mampu meningkatkan sikap siswa didalam kelas.

\section{UCAPAN TERIMA KASIH}

Peneliti mengucapkan terimakasih kepada SDN 124/VIII Sidorejo, siswa dan siswi SDN 124/VIII Sidorejo dan seluruh pihak yang telah mendukung sehingga artikel ini dapat selesai dengan baik.

\section{REFERENSI}

[1] Undang-undang No 20 Tahun 2003 Tentang Sistem Pendiidkan Nasional

[2] Astalini., Kurniawan, D. A., Perdana, R., \& Kurniasari, D. "Identification of Student Attitudes toward Physics Learning at Batanghari District High School". The Educational Review, USA, 2(9), 475-484. https://doi.org/10.26855/er.2018.09.003. 2018

[3] Asrial, Syahrial, kurniawan, D, A, perdana, R, Nugroho, P. Supporting Technology 4.0: Ethoconstructivist Multimedia for Elementary Schools. IJOE. Vol. 15. No. 14. 2019.

[4] Kusniati, M \& Pamelasari, S.D. Penerapan Critical Review Terhadap Buku Guru Ipa Kurikulum 2013 Untuk Mengembangkan Kemampuan Mahasiswa Dalam Menyusun Perangkat Pembelajaran Berpendekatan Saintifik. Jurnal Pendidikan IPA Indonesia. Vol.3 No.2. pp 168-178. 2014

[5] Mulyasa. (2015). Pengembangan dan Implementasi kurikulum 2013.Bandung: Remaja Rosdakarya

[6] Bakhtiar, A.,M, \& Nugroho, A.,S. (2016). Curriculum Development of Environmental Education Based on Local Wisdom at Elementary School. International Journal of Learning, Teaching and Educational Research, 15, 24. 
[7] Astalini, Kurniawan, D, A, Melsayanti, R, Destianti, A. Sikap Terhadap Mata Pelajaran Ipa Di Smp Se-Kabupaten Muaro Jambi. Jurnal Lentera Pendidikan. Vol. 21 No.2. pp. 214-227. 2018.

[8] MDACHI, Stephen J, M. Giving thought to students' alternative conceptions in stereochemistry: One teacher's basis for pedagogical content knowledge improvement." Journal of Turkish Science Education. Vol. 9. No 4. pp. 22-34. 2012.

[9] Astalini, Kurniawan, D, A., Putri, A, D., Identifikasi Sikap Implikasi Sosial Dari Ipa, Ketertarikan Menambah Waktu Belajar Ipa, Dan Ketertarikan Berkarir Dibidang Ipa Siswa Smp Se-Kabupaten Muaro Jambi. Jurnal Tarbiyah: Jurnal Ilmiah Kependidikan. Vol. 7 No. 2. Pp. 93-108. 2018.

[10] Astalini, A., Kurniawan, D. A., Melsayanti, R., \& Destianti, A. Sikap terhadap mata pelajaran ipa di smp sekabupaten muaro jambi. Lentera Pendidikan: Jurnal Ilmu Tarbiyah dan Keguruan, 21(2), 214-227. 2018.

[11] Creswell, J. W. Educational Research: Planning, Conducting and Evaluating Quantitative and Qualitative Research (4th ed.). Boston: Edwards Brothers, Inc. 2012

[12] Kerlinger, F, N. Foundations Of Behavioural Research. Yogyakarta: Gadjah Mada University Press. 2014.

[13] Astalini, Kurniawan, D, A., Perdana, R, Pathoni, H. Identifikasi Sikap Peserta Didik terhadap Mata Pelajaran Fisika di Sekolah Menengah Atas Negeri 5 Kota Jambi. Unnes Physics Education Journal. Vol. 8 No. 1. 2019.

[14] Surahman, Paudi, R, I \& Tureni, D., Meningkatkan Hasil Belajar Siswa Dalam Pembelajaran IPA Pokok Bahasan Makhluk Hidup Dan Proses Kehidupan Melalui Media Gambar Kontekstual Pada Siswa Kelas II SD Alkhairaat Towera. Jurnal Kreatif Tadulako Online. Vol. 3 No. 4. Pp 91-107. 2014.

[15] Sulthon., Pembelajaran Ipa Yang Efektif Dan Menyenangkan Bagi Siswa Madrasah Ibtidaiyah (Mi). Jurnal ELEMENTARY. Vol. 4 No. 1. Pp 38-54. 2016.

[16] Kurniasih, D. Peningkatan Minat Dan Hasil Belajar Ipa Melalui Model Pembelajaran Think Pair Share. Natural: Jurnal Ilmiah Pendiidkan IPA. Vol. 5 No.1. pp 7-11. 2018.

[17] Astalini, Kurniawan, D, A., Putri, A, D., Identifikasi Sikap Implikasi Sosial Dari Ipa, Ketertarikan Menambah Waktu Belajar Ipa, Dan Ketertarikan Berkarir Dibidang Ipa Siswa Smp Se-Kabupaten Muaro Jambi. Jurnal Tarbiyah: Jurnal Ilmiah Kependidikan. Vol. 7 No. 2. Pp. 93-108. 2018.

[18] Astalini, Kurniawan, D, A., Putri, A, D., Identifikasi Sikap Implikasi Sosial Dari Ipa, Ketertarikan Menambah Waktu Belajar Ipa, Dan Ketertarikan Berkarir Dibidang Ipa Siswa Smp Se-Kabupaten Muaro Jambi. Jurnal Tarbiyah: Jurnal Ilmiah Kependidikan. Vol. 7 No. 2. Pp. 93-108. 2018.

[19] Astalini, Kurniawan, D, A, Perdana, R, Kurniawan, W. Identification Attitudes of Learners on Physics Subjects. Journal of Education Science and Technology. Vol 5 No 1.2019. 